\title{
Interest Of Vocational School Students In The Selection Of Building Engineering Study Program Palangka Raya University In Class Xii Of SMk N 1 Palangka Raya
}

\author{
Minat Siswa Smk Terhadap Pemilihan Program Studi Pendidikan Teknik Bangunan \\ Universitas Palangka Raya Pada Kelas Xil Smk N 1 Palangka Raya
}

David Pratama Putra ${ }^{1}$, Wiratno ${ }^{2}$, Revianti Coenraad ${ }^{3}$

\author{
${ }^{1}$ Program Studi Pendidikan Teknik Bangunan, Jurusan Pendidikan Teknologi dan Kejuruan \\ Fakultas Keguruan dan Ilmu Pendidikan, Universitas Palangka Raya \\ e-mail: david.pratamaptb@gmail.com
}

\begin{abstract}
This study is descriptive research with a quantitative approach, the research subjects as many as 131 students from 7 different skill program classes in class XII SMK N 1 Palangka Raya. The questionnaire uses a likert scale and is created in the form of a Google form, then distributed online to students. After that, the data is analyzed using the achievement degree formula (DP) and multiple linear regression analysis. The results showed that the average percentage of interest of students of SMK N 1 Palangka Raya towards the selection of Program Building Engineering Education Study of Palangka Raya University amounted to $72.67 \%$ and belonged to the category of quite in demand. While the factors that affect the interest of students of SMK N 1 Palangka Raya continue their studies in the Building Engineering Education Study Program of The University of Palangka Raya, namely self-motivation factors, opportunity factors, social environmental factors and institutional factors are simultaneously indicated with a significance value of less than 0.05 and Fcalculated greater than Ftable $(41,898$ > 2.44). The most partially significant factor is the institutional factor with tcalculated value greater than the ttable value (7.605 > 1.97897). This research can be developed again, considering that only $55.7 \%$ of the free variables discussed in this study are able to explain bound variables, in addition this study can be used as an evaluation material on improving the promotion of PTB UPR Study Program.
\end{abstract}

Keywords: Interests, Vocational School, Building Engineering Education

\section{PENDAHULUAN}

Keputusan dalam memilih jurusan di perguruan tinggi bagi seorang remaja khususnya pada siswa kelas XII SMA/SMK atau sederajat merupakan suatu keputusan yang cukup berat. Hal ini dilandaskan pada penentuan karier untuk masa depan remaja tersebut. Keinginan kuat yang timbul dari hati dan tidak terpengaruh oleh orang lain pada sesuatu merupakan kecenderungan seseorang memiliki minat yang kuat pada hal tersebut. Semakin kuat ketertarikan yang ada maka semakin besar minat bertumbuh kembang pada diri seseorang [1]. Minat melanjutkan studi ke perguruan tinggi adalah kecenderungan yang mengarahkan siswa untuk memilih perguruan tinggi sebagai kelanjutan setelah lulus sekolah menengah yang ditandai dengan perasaan senang, adanya keinginan perhatian, dorongan dan kemauan, kebutuhan dan harapan [2].

Pendidikan tinggi merupakan lanjutan dari pendidikan menengah yang diselenggarakan oleh perguruan tinggi yang mencakup program pendidikan diploma, sarjana, magister, spesialis dan doktor. Perguruan tinggi sebagai wadah atau tempat mengembangkan ilmu pengetahuan dan keterampilan diharapkan dapat membantu mempersiapkan generasi muda membuka peluang karier yang lebih baik. 
Program Studi Pendidikan Teknik Bangunan Universitas Palangka Raya adalah salah satu program studi dari Fakultas Keguruan dan Ilmu Pendidikan Universitas Palangka Raya yang menyelenggarakan studi dengan Iulusan menjadi Sarjana (S.Pd) dengan kompetensi utama menjadi guru dibidang kejuruan khususnya di SMK dengan rumpun teknologi dan rekayasa. Selain menjadi guru SMK, prospek kerja lulusan PTB lainnya yaitu dosen, praktisi industri, PNS, konsultan bangunan, dsb. Dengan prospek kerja yang bervariasi tentu seharusnya dapat menarik banyak minat siswa terkhususnya siswa SMK dengan jurusan teknologi dan rekayasa yang masih satu rumpun ilmu.

Dari survei pendahuluan yang telah dilakukan, terdapat kesenjangan pada jumlah mahasiswa baru yang masuk di PTB pada tahun 2016-2020. Hal-hal yang dimaksud, dapat ditunjukkan pada Tabel 1.

Tabel 1. Jumlah Mahasiswa Baru Yang Masuk Tahun 2016 - 2020 Prodi Pendidikan Teknik Bangunan

\begin{tabular}{|c|c|c|c|c|c|}
\hline \multirow{2}{*}{ Program Studi } & \multicolumn{5}{|c|}{ Jumlah Mahasiswa/Tahun } \\
\cline { 2 - 6 } & 2016 & 2017 & 2018 & 2019 & 2020 \\
\hline Pendidikan Teknik Bangunan & 14 & 29 & 42 & 22 & 10 \\
\hline
\end{tabular}

Sumber: Data Olahan (2021)

Berdasarkan dari permasalahan yang ada peneliti dapat mengetahui seberapa besar minat siswa khususnya siswa SMK terhadap Program Studi Pendidikan Teknik Bangunan Universitas Palangka Raya sebagai pilihan kelanjutan studinya.

\section{METODOLOGI PENELITIAN}

Pada penelitian ini digunakan pendekatan penelitian deskriptif dan metode penelitian kuantitatif. Menurut Sugiyono (2011: 199), "penelitian deskriptif bertujuan untuk menggambarkan secara sistematik dan akurat fakta dan karakteristik mengenai populasi atau bidang tertentu" [3]. Sedangkan metode kuantitaif dipilih untuk mempermudah analisis dalam perhitungan hasil yang menggambarkan fakta pada lapangan untuk diubah menjadi data kuantitatif/statistik. Populasi dalam penelitian ini terdiri dari 7 kelas XII di SMK N 1 Palangka Raya dengan jurusan yang berbeda-beda tetapi masih berkaitan dengan Program Studi Pendidikan Teknik Bangunan berjumlah sebanyak 194 orang.

Teknik sampling yang digunakan yaitu teknik sampling acak sederhana (simple random sampling) dan Formula Slovin, dari hasil perhitungan didapatkan jumlah sampel pada penelitian ini sebanyak 131 orang. Teknik pengumpulan data berupa kuesioner/angket, dengan kelebihan yaitu praktis dalam segi waktu, ekonomis dalam segi biaya dan responden dapat menjawab bebas tanpa pengaruh orang lain. Kuesioner angket dalam bentuk google form karena lebih mudah dalam pembuatan, pendistribusian, pengisian dari responden dan pengumpulan datanya serta untuk menjaga social distancing pada masa pandemi covid-19.

Pengukuran komponen angket atau kuesioner menggunakan skala likert empat skala, Penggunaan skala likert dengan empat skala bertujuan untuk dapat menjaring data penelitian lebih akurat dikarenakan kategori jawaban undeciden yang mempunyai arti ganda sehingga dapat menimbulkan (central tendency effect) yang dapat menghilangkan banyak data penelitian dan berdampak mengurangi banyaknya informasi yang dapat dijaring dari responden [4]. Skala likert dengan empat kategori jawaban dinyatakan dalam tabel 2.

Tabel 2. Skor Skala Likert

\begin{tabular}{|l|c|}
\hline \multicolumn{1}{|c|}{ Kategori Jawaban Responden } & Skor Butiran \\
\hline Sangat Setuju (SS) & 4 \\
\hline Setuju (S) & 3 \\
\hline Tidak Setuju (TS) & 2 \\
\hline Sangat Tidak Setuju (STS) & 1 \\
\hline
\end{tabular}

Sumber: (Hadi, 1991)

Penelitian ini menggunakan hubungan variabel multivariat yaitu hubungan antara 3 variabel atau lebih, yang terdiri dari 2 jenis variabel yakni variabel bebas dan variabel terikat. Variabel bebas yaitu faktor-faktor 
yang mempengaruhi minat siswa melanjutkan studi ke Program Studi Pendidikan Teknik Bangunan UPR yang terbagi menjadi beberapa sub variabel yaitu faktor motivasi diri (X1), faktor peluang (X2), faktor lingkungan sosial (X3) dan faktor institusional (X4). Variabel terikat yaitu minat siswa terhadap pemilihan Program Studi Pendidikan Teknik Bangunan UPR (Y).

Teknik analisis data, yaitu:

1. Uji Instrumen

a. Uji validitas

Uji validitas menggunakan teknik korelasi Product Moment Pearson, yaitu:

$$
r_{\mathrm{xy}} \quad=\frac{n \sum x y-\left(\sum x\right)(\Sigma y)}{\sqrt{\left\{n \cdot \Sigma x^{2}-(\Sigma x)^{2}\right\} n \cdot \Sigma y^{2}-(\Sigma y)^{23}}}
$$

b. Uji reliabilitas

Pengujian reliabilitas instrumen dalam penelitian ini menggunakan Rumus Alpha Cronbach, yaitu sebagai berikut:

$$
r_{11}=\left(\frac{n}{n-1}\right)\left(1-\frac{\sum \sigma_{t}^{2}}{\sigma_{t}^{2}}\right)
$$

c. Uji normalitas

Uji normalitas dalam penelitian ini menggunakan Metode Kolmogorov-Smirnov dengan ketentuan sebagai berikut:

- Jika taraf sig >0,05; maka dapat disimpulkan sebaran data terdistribusi normal

- Jika taraf sig <0,05; maka dapat disimpulkan bahwa sebaran data tidak terdistribusi normal

2. Analisis Deskriptif Persentase

Pada penelitian ini digunakan teknik analisis data statistik deskriptif dengan tujuan dapat menggambarkan atau mendeskripsikan objek penelitian sebagaimana adanya. Sehingga faktor serta minat terhadap Program Studi Pendidikan Teknik Bangunan UPR dapat diungkapkan sesuai dengan kondisi di lapangan. Prosedur-prosedur untuk analisis data deskriptif persentase adalah sebagai berikut:

a. Tabulasi data dan menjumlahkan skor jawaban dari lembar kuesioner yang telah diperoleh dari responden.

b. Memasukkan skor tersebut ke dalam rumus sebagai berikut:

$$
D P=\frac{\sum x}{n x \text { Eitem } x \text { skala terting gi likert }} \times 100 \%
$$

c. Setelah skor didapatkan, data yang telah dihitung dideskripsikan dalam bentuk kalimat kualitatif. Dengan cara membuat seperti tabel 3. kategori derajat pencapaian dengan membagi menjadi beberapa kriteria data.

Tabel 3. Kategori Derajat Pencapaian

\begin{tabular}{|c|c|}
\hline Persentase (\%) & Kriteria \\
\hline $90 \%-100 \%$ & Sangat berminat \\
\hline $80 \%-89 \%$ & Berminat \\
\hline $65 \%-79 \%$ & Cukup berminat \\
\hline $55 \%-64 \%$ & Kurang berminat \\
\hline $0 \%-54 \%$ & Tidak berminat \\
\hline
\end{tabular}

Sumber: (Arnold., Rani, Iskandar G., 2019) 
3. Analisis Regresi Linear berganda

Regresi Linear Berganda (multiple linear regression) adalah model regresi linear dengan melibatkan lebih dari satu variabel bebas atau predictor. Analisis regresi berganda bertujuan untuk mengetahui dan mengukur pengaruh antara satu atau lebih variabel bebas (independen) terhadap variabel terikat (dependen). Model regresi linier berganda ditunjukkan pada persamaan berikut:

$$
Y=a+b 1 X 1+b 2 X 2+\ldots+b n X n+\varepsilon
$$

.4

\section{HASIL DAN PEMBAHASAN}

Berikut adalah hasil perhitungan penelitian dengan menggunakan bantuan program SPSS v16.0:

1. Uji Instrumen

Berdasarkan hasil analisis pada pengujian validitas diperoleh nilai $r_{\text {hitung }}>r_{\text {tabel }}$ yaitu nilai $r_{\text {hitung }}$ dari seluruh pernyataan (32 butir) lebih besar dari nilai $r_{\text {tabel }}(0,1716)$ sehingga dapat disimpulkan instrumen penelitian valid. Untuk pengujian reliabilitas diperoleh seluruh variabel memiliki nilai Alpha Cronbach lebih dari 0,6 $(\alpha>0,6)$ sehingga dapat disimpulkan bahwa instrumen penelitian ini reliabel. Dan pada uji normalitas diperoleh nilai signifikansi sebesar 0,093 lebih besar dari 0,05 sehingga dapat disimpulkan sampel yang digunakan berdistribusi normal.

2. Analisis Deskriptif Persentase

Data skor yang diperoleh dari angket/kuesioner terdiri dari 32 butir pernyataan dan dinyatakan pada tabel 4 di bawah ini.

Tabel 4. Perhitungan Statistik Total Skor Angket/Kuesioner

\begin{tabular}{|l|l|r|}
\hline N & Valid & 131 \\
\cline { 2 - 3 } & Missing & 0 \\
\hline Mean & 93,02 \\
\hline Median & 95,00 \\
\hline Mode & 96 \\
\hline Std. Deviation & 11,058 \\
\hline Minimum & 63 \\
\hline Maximum & 128 \\
\hline Sum & 12186 \\
\hline
\end{tabular}

Sumber: Hasil Perhitungan Menggunakan SPSS (2021)

Berdasarkan tabel 8 diperoleh skor yang didapat rata-rata (mean) sebesar 93,02, skor tengah (median) sebesar 95,00, skor yang sering muncul (mode) 96, simpangan baku (std. deviation) sebesar 11,058 dan total skor (sum) sebesar 12186. Kemudian dilakukan perhitungan DP dari responden dan diperoleh hasil pengukuran sebagai berikut.

$$
\begin{aligned}
\mathrm{DP} & =\frac{\sum x}{n x \sum \text { item } x \text { skala terting gi likert }} \times 100 \% \\
\mathrm{D} & =\frac{12186}{131 \times 32 \times 4} \times 100 \% \\
\mathrm{D} & =\frac{12186}{16768} \times 100 \% \\
\mathrm{D} & =0,72674 \times 100 \% \\
\mathrm{D} & =72,67 \%
\end{aligned}
$$

3. Analisis Regresi Linear Berganda

Hasil regresi menggunakan SPSS dijabarkan sebagai berikut:

a. Uji signifikan simultan 
ANOVA ${ }^{\text {b }}$

\begin{tabular}{|ll|r|r|r|r|r|}
\hline \multicolumn{1}{|c|}{} & \multicolumn{1}{c|}{$\begin{array}{c}\text { Sum of } \\
\text { Squdel }\end{array}$} & & $\mathrm{df}$ & Mean Square & \multicolumn{1}{c|}{$\mathrm{F}$} & Sig. \\
\hline 1 & Regression & 122.498 & 4 & 30.624 & 41.898 & $.000^{=}$ \\
& Residual & 92.098 & 126 & .731 & & \\
& Total & 214.595 & 130 & & & \\
\hline
\end{tabular}

a. Predictors: (Constant), $\times 4, \times 1, \times 3, \times 2$

b. Dependent Variable: $Y$

\section{Gambar 1. Output Tabel ANOVA atau F Test}

Berdasarkan tabel ANOVA atau $F$ tes di atas, diperoleh nilai $F$ hitung sebesar 41,898 dengan probalilitas 0,000. Oleh karena probabilitas lebih kecil dari 0,05 dan Fhitung lebih besar dari Ftabel $(F(4 ; 127))$ yaitu $41,898>2,44$.

b. Uji signifikan parameter

Interprestasi koefisien parameter variabel independen menggunakan unstandardized coefficients dan dinyatakan pada gambar 2 .

\begin{tabular}{|c|c|c|c|c|c|c|}
\hline \multicolumn{7}{|c|}{ Coefficients } \\
\hline \multirow{2}{*}{\multicolumn{2}{|c|}{ Madel }} & \multicolumn{2}{|c|}{ Unstandardized Coefficients } & \multirow{2}{*}{$\begin{array}{c}\begin{array}{c}\text { Standardized } \\
\text { Coefficients }\end{array} \\
\text { Beta } \\
\end{array}$} & \multirow[b]{2}{*}{$t$} & \multirow[b]{2}{*}{ Siq. } \\
\hline & & B & Std. Error & & & \\
\hline 1 & (Constant) & -1.779 & .669 & & -2.657 & .009 \\
\hline & $\times 1$ & .079 & .041 & .138 & 1.932 & .056 \\
\hline & $\times 2$ & .091 & .042 & .203 & 2.180 & .031 \\
\hline & $\times 3$ & -.066 & .037 & -.164 & -1.765 & .080 \\
\hline & $\times 4$ & .220 & .029 & .639 & 7.605 & .000 \\
\hline
\end{tabular}

a. Dependent Variable: $Y$

Gambar 2. Output Koefisien Regresi

Dari keempat variabel independen yang dimasukkan dalam model, hanya dua variabel (X2 \& X4) yang signifikan pada $\alpha=5 \%$, hal ini terlihat dari probabilitas signifikansi keduanya jauh dibawah 0,05 . Dua variabel lainnya (X1 dan X3) berpengaruh signifikan pada $\alpha=10 \%$ yang terlihat dari probabilitas signifikansi dibawah 0,10 . Sehingga diperoleh persamaan matematis sebagai berikut:

$Y=-1,779+0,079 \times 1+0,091 X 2-0,066 X 3+0,220 X 4+\varepsilon$ .5

c. Uji statistik $t$

Uji t digunakan untuk menguji bagaimana pengaruh masing-masing variabel bebasnya secara sendirisendiri terhadap variabel terikatnya. Hasil uji t dibandingkan antara nilai thitung dan ttabel, ttabel digunakan untuk menguji pengaruh variabel bebas terhadap variabel terikat secara parsial. Nilai thitung dan nilai signifikansi dapat dilihat pada gambar 3 .

Coefficients ${ }^{3}$

\begin{tabular}{|c|c|c|c|c|c|c|}
\hline & & Unstandardi & Coefficients & $\begin{array}{l}\text { Standardized } \\
\text { Coefficients }\end{array}$ & & \\
\hline & & B & Std. Error & Beta & $t$ & Siq. \\
\hline 1 & (Constant) & -1.779 & .669 & & -2.657 & .009 \\
\hline & $\mathrm{x} 1$ & .079 & .041 & .138 & 1.932 & .056 \\
\hline & $\times 2$ & .091 & .042 & .203 & 2.180 & .031 \\
\hline & $\times 3$ & -.066 & .037 & -.164 & -1.765 & .080 \\
\hline & $\times 4$ & .220 & .029 & 639 & 7.605 & .000 \\
\hline
\end{tabular}

a. Dependent Variable: $Y$

Gambar 3. Output Hasil Uji t 
Nilai $t_{\text {tabel }}$ didapat dari rumus $(\alpha / 2 ; n-k-1)$ dengan $n$ adalah jumlah sampel, $k$ adalah jumlah variabel bebas, $\alpha$ adalah taraf kesalahan $5 \%$. Nilai $t_{\text {tabel }}(5 \% / 2 ; 131-4-1)$ didapatkan $(0,025 ; 126)$ sehingga diperoleh nilai $t_{\text {tabel }}$ $1,97897$.

d. Koefisien determinasi

Koefisien determinasi digunakan untuk mengetahui seberapa besar kemampuan variabel bebas dalam menjelaskan variabel terikat pada suatu penelitian. Hasil keluaran koefisien determinasi dapat dilihat pada gambar 4 di bawah ini.

\begin{tabular}{l} 
Model Summary \\
\begin{tabular}{|l|l|r|r|r|}
\hline Mode & $\mathrm{R}$ & $\mathrm{R}$ Square & $\begin{array}{c}\text { Adjusted R } \\
\text { Square }\end{array}$ & $\begin{array}{c}\text { Std. Error of } \\
\text { the Estimate }\end{array}$ \\
\hline 1 & $.756^{\mathrm{a}}$ & .571 & .557 & .855 \\
\hline
\end{tabular} \\
\hline
\end{tabular}

Uji instrumen telah memenuhi seluruh ketentuan, baik uji validitas, uji reliabilitas dan uji normalitas. Uji validitas menggunakan teknik korelasi Bivariate Pearson (produk momen pearson) dengan taraf kesalahan 0,05 (5\%) diperoleh semua variabel bebas dan variabel terikat valid yang dibuktikan dengan nilai rhitung $>$ rtabel. Uji reliabilitas instrumen menggunakan rumus Alpha Cronbach dan diperoleh bahwa semua variabel bebas dan variabel terikat reliabel yang dibuktikan dengan nilai $\alpha>0,6$. Sedangkan uji normalitas menggunakan metode Kolmogrov-Smirnov diperoleh bahwa sampel yang digunakan berdistribusi normal yang dibuktikan dengan hasil nilai signifikansi lebih besar dari taraf signifikansi 0,05 yang disyaratkan.

Pada analisis deskripsi persentase dilakukan perhitungan secara menyeluruh pada setiap jumlah skor masing-masing variabel bebas dan variabel terikat sehingga diperoleh total skor untuk menghitung berapa persentase rata-rata minat siswa terhadap pemilihan Prodi PTB UPR. Perhitungan dilakukan dengan bantuan program SPSS v16.0 menggunakan teknik statistik deskripsi dan rumus derajat pencapaian responden diperoleh nilai persentase rata-rata minat siswa terhadap pemilihan Prodi PTB UPR sebesar $72,67 \%$ dan termasuk dalam kategori cukup berminat.

Analisis regresi linear berganda terdiri dari uji signifikansi simultan, uji signifikansi parameter, uji statistik $\mathrm{t}$ dan koefisien determinan. Pada uji signifikansi simultan keempat variabel independen (X1, X2, X3 \& X4) berpengaruh secara simultan terhadap variabel dependen $(Y)$ dibuktikan dengan nilai signifikansi kurang dari 0,050 dan nilai Fhitung lebih besar dari Ftabel $(41,898>2,44)$. Uji signifikansi parameter digunakan untuk mengetahui ada tidaknya hubungan parameter didalam model regresi. Dari keempat variabel independen, tiga variabel (X1, X2 \& X4) berpengaruh secara positif dan signifikan, namun variabel X3 bernilai negatif. Pada uji statistik t, variabel X2 dan X4 berpengaruh positif dan signifikan terhadap variabel $Y$ ditunjukkan dengan nilai signifikansi kurang dari 0,05 dan thitung lebih besar dari ttabel. Sehingga disimpulkan terdapat pengaruh faktor peluang dan faktor institusional terhadap minat siswa terhadap pemilihan Prodi PTB UPR secara parsial dapat diterima. Namun untuk variabel X1 dan X3 tidak berpengaruh secara signifikan terhadap variabel Y secara parsial. Untuk nilai koefisien determinan diperoleh 0,557 sehingga disimpulkan kemampuan variabel bebas (independen) dalam menjelaskan variabel terikat (dependen) sebesar 55,7\% dan sisanya 44,3\% dijelaskan oleh variabel lain yang tidak dibahas dalam penelitian ini.

\section{PENUTUP}

KESIMPULAN

Dari hasil analisa terhadap hasil pengolahan data yang telah dilakukan maka dapat ditarik kesimpulan, yaitu:

1. Rata-rata persentase minat siswa SMK N 1 Palangka Raya terhadap pemilihan Program Studi Pendidikan Teknik Bangunan Universitas Palangka Raya sebesar 72,67\% dan termasuk dalam kategori cukup diminati.

2. Dari perhitungan menggunakan regresi linear berganda didapatkan bahwa keempat variabel bebas/independen (faktor motivasi diri, faktor peluang, faktor lingkungan sosial dan faktor institusional) 
berpengaruh positif dan signifikan secara simultan dengan tingkat signifikansi $0,000<0,050$ serta nilai Fhitung lebih besar dari Ftabel $(41,898>2,44)$.

3. Faktor yang paling berpengaruh secara signifikan yaitu faktor institusional secara parsial dengan tingkat signifikansi paling rendah $(0,000<0,050)$ serta nilai thitung paling tinggi dan lebih besar dari ttabel $(7,605$ $>1,97897)$.

4. Nilai koefisien determinan diperoleh sebesar 0,557 sehingga diartikan bahwa kemampuan variabel bebas (independen) dalam menjelaskan variabel terikat (dependen) sebesar $55,7 \%$ dan sisanya $44,3 \%$ dijelaskan oleh variabel lain yang tidak dibahas dalam penelitian ini

\section{SARAN}

Rekomendasi yang dapat diberikan, sebagai berikut:

1. Penelitian ini dapat dikembangkan lagi oleh peneliti selanjutnya, mengingat hanya $55,7 \%$ variabel bebas yang dibahas dalam penelitian ini mampu menjelaskan variabel terikat sehingga penelitian ini dapat semakin sempurna ke depannya.

2. Bagi Program Studi Pendidikan Teknik Bangunan UPR, penelitian ini dapat dimanfaatkan sebagai motivasi dan bahan evaluasi dalam peningkatan promosi program studi dalam menarik minat calon mahasiswa.

\section{DAFTAR PUSTAKA}

[1] N. Indriyanti, Siswandari, and E. Ivada, "Faktor-Faktor Yang Memengaruhi Minat Melanjutkan Pendidikan Ke Perguruan Tinggi Pada Siswa Kelas XII Akuntansi SMK Negeri 6 Surakarta Tahun 2013," Jupe UNS, vol. 1, no. 2, pp. 1-9, 2013.

[2] M. Syah, Psikologi Belajar. Jakarta: Raja Grafindo Persada, 2009.

[3] Sugiyono, Metode Penelitian Kuantitatif Kualitatif dan R \& D. Bandung: Alfabeta, 2011.

[4] S. Hadi, Analisis Butir untuk Instrumen Angket, Tes, dan Skala Nilai. Yogyakarta: FP UGM, 1991.

[5] Trissan, W. (2018). Application of the Snowball Throwing Cooperative Learning Model on Transportation Engineering Education Fkip University of Palangka Raya Academic Year 2017/2018. BALANGA: Jurnal Pendidikan Teknologi dan Kejuruan, 6(2), 9-14. 